\title{
Daya Hambat Ekstrak Buah Delima Merah (Punica granatum Linn) terhadap Pertumbuhan Staphylococcus aureus (The Inhibition of Red Pomegranate Fruit Extract (Punica granatum Linn) on The Growth of Staphylococcus aureus)
}

\author{
Erlita Prestiandari ${ }^{1}$, Sri Hernawati ${ }^{2}$, Leni Rohma Dewi ${ }^{3}$ \\ ${ }^{1}$ Fakultas Kedokteran Gigi Universitas Jember \\ ${ }^{2}$ Bagian Oral Medicine, Fakultas Kedokteran Gigi, Universitas Jember \\ Jalan Kalimantan 37, Jember 68121 \\ Erlita.tyarlie@gmail.com
}

\begin{abstract}
Background: Staphylococcus aureus is the most common microorganism in angular cheilitis. Angular cheilitis is inflammation in one corner of the mouth or both corners of the mouth may extend involving the lips commisura and surrounding skin. The prevalence of angular cheilitis is $0.2-15.1 \%$ in children and $0.7-3.8 \%$ in adults. One of alternative treatment by using herbal plants, namely red pomegranate. Red pomegranate contains flavonoids, tannins, and alkaloids as antibacterial. Objective: to determine the inhibition of red pomegranate extract on growth of Staphylococcus aureus. Methods: disk diffusion method with 6 samples in each study group. The study group consisted of 4 treatment groups (25\%,50\%, $75 \%$ and $100 \%$ red pomegranate extract), positive control group (fusidic acid), and negative control group (sterile aquades). Data were analyzed using One Way Anova test and LSD (Least Significant Difference) test. Results and conclusions: red pomegranate extract has the ability to inhibit the growth of Staphylococcus aureus. The concentration of red pomegranate extract has the greatest inhibitory effect on $S$. aureus growth, that is $75 \%$ and $100 \%$.
\end{abstract}

Keyword: Antibacterial activity, red pomegranate fruit extract, Staphylococcus aureus, disk diffusion method

\begin{abstract}
Abstrak
Latar Belakang: Staphylococcus aureus merupakan mikroorganisme yang paling banyak dijumpai pada angular cheilitis. Angular cheilitis adalah keradangan pada salah satu sudut mulut atau kedua sudut mulut dapat meluas melibatkan komisura bibir dan kulit sekitarnya. Prevalensi terjadinya angular cheilitis yaitu $0,2-15,1 \%$ pada anak-anak dan $0,7-3,8 \%$ pada orang dewasa. Salah satu alternatif pengobatan dengan menggunakan tanaman herbal, yaitu buah delima merah. Buah delima merah mengandung flavanoid, tannin, dan alkaloid yang diduga sebagai antibakteri. Tujuan: untuk mengetahui daya hambat ekstrak buah delima merah terhadap pertumbuhan Staphylococcus aureus. Metode Penelitian: metode disk difusi dengan menggunakan 6 sampel pada setiap kelompok penelitian. Kelompok penelitian terdiri dari 4 kelompok perlakuan (ekstrak buah delima merah konsentrasi 25\%, 50\%, 75\% dan 100\%), kelompok kontrol positif (asam fusidat), dan kelompok kontrol negatif (aquades steril). Analisis data menggunakan uji One Way Anova dan uji LSD (Least Significant Difference). Hasil dan simpulan: ekstrak buah delima merah memiliki kemampuan menghambat pertumbuhan Staphylococcus aureus. Konsentrasi ekstrak buah delima merah yang memiliki daya hambat terbesar terhadap pertumbuhan S. aureus, yaitu konsentrasi $75 \%$ dan $100 \%$.
\end{abstract}

Kata Kunci: Daya antibakteri, ekstrak buah delima merah, Staphylococcus aureus, metode disk 


\section{Pendahuluan}

Staphylococcus aureus merupakan bakteri Gram positif, berbentuk kokus dan tersusun seperti buah anggur [1]. Bakteri ini merupakan salah satu mikroflora normal yang berada di dalam mulut, bilamana dipengaruhi oleh faktor predisposisi seperti perubahan kuantitas mikroorganisme menjadi tidak seimbang dan penurunan daya tahan tubuh host, maka dapat menyebabkan infeksi [2]. Salah satu infeksi pada rongga mulut dan sekitarnya yang dapat disebabkan oleh $S$. aureus adalah angular cheilitis [3]. Hal ini sesuai dengan hasil suatu penelitian menemukan bahwa $S$. aureus menjadi mikroorganisme yang paling banyak dijumpai pada penderita angular cheilitis dengan $33,3 \%$, sedangkan Candida tropicalis merupakan mikroorganisme yang paling sedikit dijumpai dengan 3,3\% [4].

Angular cheilitis yang juga disebut perleche adalah keradangan pada salah satu sudut mulut atau kedua sudut mulut dapat meluas melibatkan komisura bibir dan kulit sekitarnya [5]. Karakteristik dari angular cheilitis adalah terdapat erosi, fissure, ulserasi, dan kemerahan disertai sensasi terbakar, nyeri dan kekeringan di sudut mulut. Pada kasus yang parah, sudut mulut bisa berdarah saat membuka mulut dan menyebabkan krusta. Perkembangan penyakit ini sangat cepat. Oleh karena itu, seharusnya tidak ada penundaan dalam pengobatan jika gejala angular cheilitis terjadi dan sangat jelas [6]. Etiologi angular cheilitis biasanya dikarenakan infeksi Staphylococcus aureus atau Candida albicans dengan faktor predisposisi multipel lokal dan sistemik yang terlibat dalam inisiasi dan persistensi dari lesi. Beberapa faktor predisposisi tersebut di antaranya yaitu, defisiensi zat besi, kekurangan vitamin B, malabsorpsi (seperti Crohn's disease), diabetes, dan menurunnya dimensi vertikal karena penggunaan gigi tiruan [5]. Angular cheilitis merupakan kondisi umum, terhitung antara $0,2-15,1 \%$ lesi mukosa oral pada anak-anak dan antara $0,7-3,8 \%$ pada orang dewasa, walaupun kebanyakan lesi ini muncul pada orang dewasa usia 30-60 tahun. Lesi ini memiliki prevalensi di seluruh dunia, dan dapat terjadi pada laki laki maupun perempuan [7].

Selama ini perawatan yang dianggap sangat efektif terhadap angular cheilitis yang disebabkan oleh $S$. aureus adalah antibiotik asam fusidat. Obat ini dapat diaplikasikan pada sudut mulut [7]. Antibiotik asam fusidat adalah derivat antibiotik dari jamur Fusidium coccineum. Aktivitasnya mirip dengan penisilin tetapi lebih sempit. Asam fusidat bersifat bakteriostatik dengan mekanisme kerja yaitu menghambat sintesis protein bakteri. Zat ini aktif terhadap berbagai bakteri Gram positif terutama bakteri $S$. aureus. Namun asam fusidat dapat meningkatkan resiko resistensi apabila pemakaian jangka panjang. Selain itu, juga memiliki efek samping seperti skin rash, urticaria, dan iritasi pada sekitar infeksi [8]. Dalam mengatasi resiko resistensi serta efek samping dari antibiotik tersebut, maka diperlukan alternatif pengobatan alami.

Delima (Punica granatum Linn) merupakan salah satu tanaman herbal yang telah lama dimanfaatkan buahnya sebagai pengobatan dan pencegahan berbagai penyakit, di antaranya untuk terapi pencegahan kanker, penyakit kardiovaskuler, penyakit gigi dan mulut, dan proteksi terhadap radiasi ultraviolet [9]. Delima adalah tanaman buah-buahan yang dapat tumbuh hingga 5-8 $\mathrm{m}$. Tanaman ini diperkirakan berasal dari Iran, namun telah lama dikembangbiakan di daerah Mediterania. Tanaman ini juga banyak ditanam di daerah Cina Selatan dan Asia Tenggara [10]. Delima yang tersebar di Indonesia dikelompokkan berdasarkan warna buahnya, yakni delima putih, delima merah, dan delima hitam. Delima merah memiliki rasa lebih manis dan kandungan flavonoid lebih tinggi dibandingkan dengan delima putih [11] [12]. Penelitian Ahmet dkk mendapati bahwa buah delima merah (Punica granatum Linn) mengandung flavanoid dan phenol yang diduga efektif sebagai antibakteri [13].

Kandungan flavonoid pada delima mampu menghambat pertumbuhan bakteri dengan cara menghambat proses DNA gyrase pada bakteri. Queercetin (salah satu flavonoid pada delima) mampu membunuh bakteri dengan cara meningkatkan permeabilitas dari membaran di dalam bakteri dan merusak potensial membran, menyebabkan produksi ATP bakteri terganggu, menggangu transport membran dan pergerakan dari bakteri. Kandungan polifenol pada delima dapat berperan sebagai antibakteri dengan cara mendenaturasi enzim, selain itu juga dapat melekat pada substrat seperti mineral, vitamin, karbohidrat sehingga tidak bisa digunakan bakteri untuk metabolismenya. Polifenol juga dapat terserap pada dinding sel menyebabkan ganguan pada struktur dan fungsi membran sel [14]. 
Berdasarkan uraian di atas, maka penulis bermaksud melakukan penelitian mengenai daya hambat ekstrak buah delima merah terhadap pertumbuhan $S$. aureus dengan menggunakan konsentrasi $25 \%, 50 \%, 75 \%$, dan $100 \%$.

\section{Metode Penelitian}

Jenis penelitian yang dilakukan merupakan penelitian experimental laboratories dengan menggunakan rancangan the post test only control group design. Penelitian ini dilakukan pada bulan Oktober sampai November 2017 di Laboratorium Biosience Fakultas Kedokteran Gigi Universitas Jember. Jumlah keseluruhan sampel penelitian yang digunakan sebanyak 36 sampel; terdiri dari 6 kelompok penelitian yaitu ekstrak buah delima merah dengan konsentrasi $100 \%, 75 \%, 50 \%$, $25 \%$, antibiotik asam fusidat (kontrol positif) dan aquades steril (kontrol negatif) dengan besar sampel sebanyak 6 untuk setiap kelompok penelitian. Metode uji antibakteri yang digunakan adalah disk difusi. Masing-masing kelompok perlakuan, kontrol positif, dan kontrol negatif diteteskan pada blank paper disk sebanyak $20 \mu \mathrm{L}$ dengan menggunakan mikropipet. Kemudian disk diletakkan pada media MHA (Meuller-Hinton Agar) yang telah diinokulasi suspensi bakteri dengan menggunakan pinset steril. Hal tersebut diulangi pada petridish ke-2, 3, 4, 5, dan 6. Semua petridish dimasukkan dalam desikator dan inkubasi selama 24 jam pada suhu $35^{\circ} \mathrm{C} \pm 2^{\circ} \mathrm{C}$ menggunakan inkubator. Diameter zona hambat yang terbentuk diukur menggunakan jangka sorong (Gambar 1.) dan data dicatat dalam satuan milimeter.

Data hasil penelitian kemudian di tabulasi dan dilakukan analisis secara statistik. Uji Normalitas dengan menggunakan KolmogorovSmirnov dan Uji Homogenitas dengan menggunakan Levene's test. Apabila hasil menunjukkan data terdistribusi normal dan homogen $(p>0,05)$ maka dilakukan uji statistik parametrik One Way Anova dilanjutkan dengan LSD (Least Significant Differences). Apabila hasil uji menunjukkan data tidak terdistribusi normal dan/atau tidak homogen maka dapat dilakukan uji statistik nonparametrik KruskalWallis dilanjutkan dengan Mann-Whitney.

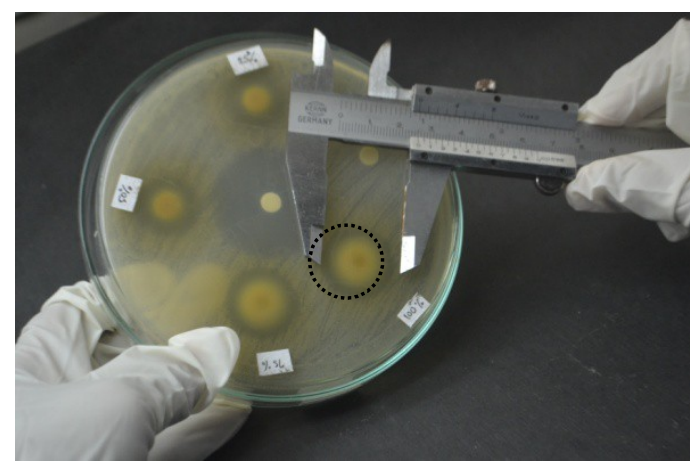

Gambar 1. Pengukuran zona hambat disekitar disk

\section{Hasil Penelitian}

Hasil penelitian mengenai daya hambat ekstrak buah delima merah (Punica granatum Linn) terhadap pertumbuhan Staphylococcus aureus didapatkan rata-rata diameter zona hambat dan standar deviasi masing-masing kelompok penelitian yang disajikan pada Tabel 1.

Tabel 1. Nilai rata-rata dan standar deviasi diameter zona hambat

\begin{tabular}{cccc}
\hline $\begin{array}{c}\text { Kelompok } \\
\text { Perlakuan }\end{array}$ & $\mathrm{N}$ & $\begin{array}{c}\varnothing \\
(\mathrm{mm})\end{array}$ & $\mathrm{SD}$ \\
\hline M100 & 6 & 19,67 & 0,73 \\
M75 & 6 & 19,54 & 0,94 \\
M50 & 6 & 17,04 & 0,71 \\
M25 & 6 & 15,90 & 0,37 \\
K(+) & 6 & 29,01 & 1,79 \\
K(-) & 6 & 0.00 & 0.00 \\
\hline
\end{tabular}

Keterangan :

$\mathrm{n} \quad$ : Jumlah sampel

$\varnothing \quad$ : Nilai rata-rata diameter zona hambat

SD : Standar deviasi (simpangan baku) zona hambat

M100 : Ekstrak buah delima merah konsentrasi $100 \%$

M75 : Ekstrak buah delima merah konsentrasi $75 \%$

M50 : Ekstrak buah delima merah konsentrasi 50\%

M25 : Ekstrak buah delima merah konsentrasi $25 \%$

$\mathrm{K}(+) \quad$ : Kontrol positif (Asam fusidat)

$\mathrm{K}(-) \quad$ : Kontrol negatif (aquades steril)

Berdasarkan perhitungan yang telah dilakukan, nilai rata-rata diameter zona hambat terbesar terdapat pada kelompok $\mathrm{K}(+)$, yaitu sebesar 29,01 mm, kemudian berturut-turut diikuti dengan kelompok M100 sebesar 19,67 $\mathrm{mm}$, kelompok M75 sebesar 19,54 mm, 
kelompok M50 sebesar 17,04 mm, dan kelompok M25 sebesar 15,90Kelompok K(-) tidak memiliki daya hambat karena nilai rata-rata diameter zona hambatnya sebesar 0,00 $\mathrm{mm}$.

Data nilai rata-rata diameter zona hambat pada masing-masing kelompok sampel selanjutnya dianalisis secara statistik untuk mengetahui apakah data pada masing-masing kelompok sampel berdistribusi normal atau tidak dengan menggunakan uji normalitas Kolmogorov-Smirnov. Hasil uji KolmogorovSmirnov diperoleh nilai signifikansi (p) lebih besar dari 0,05 sehingga dapat disimpulkan bahwa data berdistribusi normal. Setelah data diketahui berdistribusi normal, dilanjutkan dengan uji homogenitas menggunakan Levene's test. Hasil uji Levene's test menunjukkan nilai signifikansi ( $p$ ) lebih besar dari 0,05 sehingga dapat disimpulkan bahwa data homogen.

Berdasarkan hasil uji KolmogorovSmirnov dan uji Levene's test maka didapatkan data hasil penelitian berdistribusi normal dan homogen sehingga dilanjutkan dengan uji statistik parametrik One Way Anova. Hasil uji One Way Anova didapatkan nilai signifikansi (p) lebih kecil dari 0,05. Hal ini menunjukkan bahwa terdapat perbedaan pada seluruh kelompok penelitian. Uji statistik dilanjutkan dengan uji LSD (Least Significant Difference) untuk mengetahui apakah ada perbedaan bermakna antar kelompok penelitian. Hasil uji LSD menunjukkan bahwa $\mathrm{p}<0,05$ antara kelompok M100 dengan M50, M100 dengan M25, M100 dengan $\mathrm{K}(+)$, M100 dengan $\mathrm{K}(-), \mathrm{M} 75$ dengan M50, M75 dengan M25, M75 dengan $\mathrm{K}(+)$, M75 dengan $\mathrm{K}(-)$, M50 dengan M25, M50 dengan $\mathrm{K}(+)$, M50 dengan $\mathrm{K}(-)$, M25 dengan $\mathrm{K}(+)$, M25 dengan $\mathrm{K}(-)$, dan $\mathrm{K}(+)$ dengan $\mathrm{K}(-)$. Hal tersebut menunjukkan bahwa antar dua kelompok yang dibandingkan tersebut terdapat perbedaan yang bermakna. Sedangkan antara kelompok M100 dengan M75 tidak terdapat perbedaan yang bermakna ditandai dengan nilai $p>0,05$.

\section{Pembahasan}

Penelitian ini merupakan penelitian eksperimental laboratoris dengan tujuan untuk mengetahui daya hambat ekstrak buah delima merah (Punica granatum L.) terhadap pertumbuhan bakteri Staphylococcus aureus. Pembuatan ekstrak buah delima merah dalam penelitian ini menggunakan metode maserasi dengan pelarut etanol. Metode ekstraksi dengan cara maserasi dapat mecegah kemungkinan terjadinya kerusakan komponen senyawa kimia yang terkandung dalam ekstrak. Hal ini dapat terjadi karena metode maserasi tidak menggunakan panas [15].

Pemilihan pelarut juga merupakan salah satu faktor yang menentukan keberhasilan proses ektraksi. Pengunaan pelarut etanol pada penelitian ini dikarenakan etanol cenderung aman, tidak beracun dan tidak berbahaya. Pelarut etanol memiliki dua sisi yang terdiri dari gugus $\mathrm{OH}$ dan gugus $\mathrm{CH}_{2} \mathrm{CH}_{3}$. Gugus $\mathrm{OH}$ bersifat polar, sehingga mampu mengekstrak senyawa tannin, komponen fenolik, karotenoid, gula, asam amino dan glikosida. Gugus $\mathrm{CH}_{2} \mathrm{CH}_{3}$ yang bersifat non polar membuat etanol mampu mengekstrak kandungan minyak atsiri dan alkaloid [16].

Metode uji antibakteri yang digunakan dalam penelitian ini adalah metode disk difusi. Metode difusi merupakan metode umum yang praktis serta mudah dalam menguji kepekaan antibakteri terhadap bakteri aerob maupun bakteri fakultatif anaerob, cepat dalam pembacaan hasil dan murah, sehingga cocok untuk digunakan dalam penelitian [17]. Metode disk difusi memiliki risiko kegagalan yang lebih kecil dibanding cara lainnya karena setelah media diinokulasi suspensi bakteri, media tersebut ditempatkan secara terbalik. Hal tersebut bertujuan untuk mencegah tetesan uap air yang timbul jatuh ke atas media yang telah ditanami bakteri, tetesan ini dapat mempengaruhi hasil akhir dari inkubasi. Selain itu, dengan cara ini lebih efisien terhadap waktu yang digunakan dalam penelitian [18].

Analisis data pada penelitian ini menggunakan uji parametrik yaitu uji One Way Anova yang bertujuan untuk mengetahui nilai signifikansi pada seluruh kelompok penelitian. Hasil uji One Way Anova didapatkan nilai signifikansi $(p)$ sebesar 0,000 . Nilai $p<0,05$ menunjukkan bahwa terdapat perbedaan yang bermakna pada seluruh kelompok penelitian. Sehingga dapat disimpulkan bahwa ekstrak buah delima merah memiliki daya hambat terhadap pertumbuhan $S$. aureus.

Hasil penelitian menunjukkan bahwa nilai rata-rata diameter zona hambat kelompok $\mathrm{K}(+)$ yaitu 29,01 mm, kemudian berturut-turut diikuti dengan kelompok M100 sebesar 19,67 mm, kelompok M75 sebesar 19,54 mm, kelompok M50 sebesar $17,04 \mathrm{~mm}$, dan kelompok M25 sebesar 15,90 mm. Berdasarkan hasil penelitian tersebut menunjukkan bahwa semakin tinggi konsentrasi ekstrak buah delima merah, maka semakin besar diameter zona hambat yang terbentuk. Semakin besarnya diameter zona 
hambat yang terbentuk disebabkan karena kandungan zat antibakteri yang lebih banyak pada konsentrasi yang lebih tinggi [19].

Sifat antibakteri dapat dibedakan berdasarkan kekuatannya. Menurut Davis dan Stout, kriteria kekuatan daya antibakteri dibagi menjadi empat kelompok, yaitu diameter zona hambat $5 \mathrm{~mm}$ atau kurang dikategorikan lemah, diameter zona hambat 5-10 mm dikategorikan sedang, diameter zona hambat $10-20 \mathrm{~mm}$ dikategorikan kuat dan zona hambat $20 \mathrm{~mm}$ atau lebih dikategorikan sangat kuat [20]. Berdasarkan data hasil penelitian (Tabel 1.) diameter zona hambat kelompok ekstrak buah delima merah konsentrasi $100 \%, 75 \%, 50 \%$ dan $25 \%$ berturut-turut sebesar $19,67 \mathrm{~mm}$, $19,54 \mathrm{~mm}, 17,04 \mathrm{~mm}$, dan 15,90 mm, sehingga termasuk dalam kategori kuat. Kelompok $\mathrm{K}(+)$ termasuk dalam kategori sangat kuat karena diameter zona hambatnya sebesar $29,01 \mathrm{~mm}$ (lebih dari $20 \mathrm{~mm}$ ), sedangkan kelompok K(-) tidak memiliki daya antibakteri. Berdasarkan kategori tersebut, maka dapat diketahui bahwa ekstrak buah delima merah dengan konsentrasi $100 \%, 75 \%$, $50 \%$, dan $25 \%$ sudah memiliki kemampuan yang baik dalam menghambat pertumbuhan $S$. aureus dengan kategori kuat.

Setelah uji One Way Anova, maka dilanjutkan dengan uji LSD (Least Significant Difference) untuk mengetahui apakah ada perbedaan bermakna antar kelompok penelitian. Hasil uji LSD menunjukkan bahwa terdapat perbedaan bermakna antar kelompok penelitian yang ditandai dengan nilai signifikansi $(p)$ lebih kecil dari 0,05 , kecuali pada kelompok M75 dengan kelompok M100. Hal ini menunjukkan bahwa ekstrak buah delima merah konsentrasi $75 \%$ memiliki potensi yang hampir sama dengan ekstrak buah delima merah konsentrasi 100\% dalam menghambat pertumbuhan S.aureus. Hal ini disebabkan karena pada konsentrasi $100 \%$ konsistensi bahan ekstrak sudah hampir padat sehingga zat aktif yang terdapat dalam konsentrasi tersebut tidak efektif berdifusi ke dalam disk dan agar sehingga didapatkan hasil daya hambat bakteri tidak jauh berbeda dengan ekstrak konsentrasi $75 \%$ [21].

Zona hambat yang terbentuk di sekitar disk yang telah ditetesi ekstrak buah delima merah menunjukkan bahwa ekstrak tersebut mengandung senyawa aktif yang bersifat sebagai antibakteri. Kandungan antibakteri yang terdapat dalam buah delima merah yaitu, polifenol (flavonoid, antosianin, dan tannin di antaranya ellagic acid, ellagitannins dan punicalgin) [9]. Masing-masing zat aktif tersebut memiliki mekanisme berbeda sebagai antibakteri. Mekanisme kerja flavonoid sebagai senyawa antibakteri dibagi menjadi tiga, yaitu menghambat sintesis asam nukleat, menghambat fungsi membran sel, serta menghambat metabolisme energi [22]. Mekanismenya dalam menghambat sintesis asam nukleat adalah dengan menghambat pembentukan DNA dan RNA melalui cincin A dan $B$ yang berperan pada ikatan hidrogen. Hal ini menyebabkan penumpukan basa asam nukleat, dan terjadinya kerusakan permeabilitas dinding sel bakteri, lisosom, serta mikrosom [23]. Mekanisme dalam menghambat fungsi membran sel adalah dengan membentuk senyawa kompleks dengan protein ekstraseluler dan terlarut yang menyebabkan rusaknya membran sel bakteri dan diikuti dengan keluarnya senyawa intraseluler (Ngajow dkk, 2013). Sedangkan mekanisme flavonoid dalam menghambat metabolisme energi adalah dengan cara menghambat sitokrom $\mathrm{C}$ reduktase dan menghambat penggunaan oksigen pada bakteri. Padahal energi dibutuhkan bakteri dalam melakukan biosintesis makromolekul [23].

Tannin merupakan senyawa fenolik yang larut dalam air dan biasanya memiliki berat molekul tinggi. Buah delima memiliki kandungan tannin yang sangat tinggi terutama ellagic acid dan ellagitannin. Tannin memiliki aktifitas antibakteri dengan mengikat makromolekul sehingga tidak tersedia sumber energi bagi bakteri [14]. Tannin juga menghambat enzim reverse transkriptase dan DNA topoisomerase sehingga sel bakteri akan mati [24]. Tannin juga mempunyai target pada polipeptida dinding sel sehingga pembentukan dinding sel menjadi kurang sempurna. Hal ini menyebabkan sel bakteri menjadi lisis karena tekanan osmotik maupun fisik sehingga sel bakteri akan mati [25].

Senyawa lain yang berperan sebagai antibakteri yaitu alkaloid. Alkaloid memiliki aktivitas sebagai antibakteri karena senyawa ini dikenal sebagai interkalator DNA dan penghambatan sintesis DNA [26]. Alkaloid merupakan senyawa nitrogen heterosiklik yang mengandung paling sedikit satu atom nitrogen dan bersifat basa [27]. Gugus basa ini akan bereaksi dengan senyawa asam yang ada pada sel bakteri seperti DNA yang merupakan penyusun utama inti sel. Dengan terganggunya DNA, maka sintesis protein dan asam nukleat dalam sel akan terganggu [28].

\section{Simpulan dan Saran}


Berdasarkan hasil penelitian yang telah dilakukan dapat disimpulkan bahwa ekstrak buah delima merah (Punica granatum Linn) memiliki kemampuan menghambat pertumbuhan Staphylococcus aureus. Konsentrasi ekstrak buah delima merah yang memiliki daya hambat terbesar terhadap pertumbuhan S. aureus, yaitu konsentrasi $75 \%$ dan $100 \%$

Beberapa saran yang mungkin bermanfaat bagi penelitian selanjutnya yaitu: perlu dilakukan penelitian lebih lanjut terhadap masing-masing kandungan senyawa flavonoid, tannin, dan alkaloid dalam buah delima merah yang memiliki aktivitas antibakteri, perlu dilakukan penelitian lebih lanjut tentang biokompabilitas ekstrak buah delima merah, perlu dilakukan penelitian lebih lanjut mengenai daya hambat ekstrak buah delima merah terhadap mikroflora lain pada rongga mulut, perlu dilakukan penelitian lebih lanjut untuk menguji potensi ekstrak buah delima merah secara in vivo., perlu dilakukan uji toksisitas agar mengetahui batas maksimal konsentrasi ekstrak buah delima merah yang dapat diterima oleh tubuh., perlu dilakukan sosialisasi pada masyarakat mengenai manfaat buah delima merah terutama bagi kesehatan gigi dan mulut.

\section{Daftar Pustaka}

[1] Jawetz, Melnick, Adelberg's. Mikrobiologi kedokteran. Jakarta: Salemba Medika; 2005.

[2] Syahrurachman A, Chatim A, Soebandrio A, Karuniawati A, Santoso A, Harun B, et al, editors. 2010. Buku ajar mikrobiologi kedokteran. Edisi revisi. Jakarta: Binarupa Aksara publishers.

[3] Smith A. J, M. S. Jackson, and J. Bagg. 2001. The ecology of Staphylococcus species in the oral cavity. J. Med. Microbiol, Vol. 50 (2001), 940-946. The Pathological Society of Great Britain and Ireland.

[4] Yusran, Ali, Zohra Nazaruddin, Erni Marlina. 2011. Efikasi terapi angular cheilitis di Bagian IImu Penyakit Mulut Fakultas Kedokteran Gigi Universitas Hasanuddin berdasarkan prinsip kausatif. Fakultas Kedokteran Gigi Universitas Hasanuddin Makassar, Indonesia.

[5] Gandalfo, Sergio, Crispian Scully CBE, Marco Carrozzo. 2006. Oral Medicine. British: Churchill Livingstone Elsevier.

[6] Fajriani. 2017. Management of Angular
Cheilitis in children. Journal of Dentomaxillofacial Science (J Dentomaxillofac Sci ), April 2017, Volume 2, Number 1: 1-3. Department of Pediatric, Faculty of Dentistry, Hasanuddin University, Makassar, Indonesia.

[7] Shahzad, Mahreen, Raheela Faraz, Anam Sattar. 2014. Angular Cheilitis: Case Report And Literature Review.

[8] Umar, Ani, Dwi Krihariyani, dan Diah Titik Mutiarahati. 2012. Pengaruh Pemberian Ekstrak Daun Binahong (Andrederacordifolia (TEN) steenis) terhadap Kesembuhan Luka Infeksi Staphylococcus aureus pada Mencit. Analis Kesehatan Sains, Vol 01, no 02 2012. Jurusan Analis Kesehatan Poltekkes Kemenkes Surabaya.

[9] Jurenka, Julie. 2008. Therapeutic Application of Pomegranate (Punica granatum L.): A Review. Alternative Medicine Review, Volume 13, Number 2 2008. Thorne Research, Inc.

[10] Hardana, Hari, Efrida Warganegara. 2015. Ekstrak Buah Delima Sebagai Antibiotik Pengobatan Infeksi MRSA. Majority, Volume 4, Nomor 9 : 83-87. Bagian Mikrobiologi, Fakultas Kedokteran, Universitas Lampung.

[11] Asthon, Richard, Barbara Baer, David Silverstein. 2006. The Incredible Pomegranate. Arizona: Third Milennium Publishing.

[12] Astawan, M. 2008. Sehat dengan Buah. Cetakan Pertama. Jakarta: Penerbit Dian Rakyat.

[13] Ahmet, D. Duman, Mustafa Ozgen, Kenan S. Dayisoylu, Nurcan Erbil and Coskun Durgac. 2009. Antimicrobial Activity of Six Pomegranate (Punica granatum L.) Varieties and Their Relation to Some of Their Pomological and Phytonutrient Characteristics. Open Access Molecules. ISSN 1420-3049, pp 1809-1817.

[14] Parseh, Hoda., Shahin Hassanpour, Zahra Emam-djome, Alireza Shahab Lavasani. 2012. Antimicrobial properties of Pomegranate (Punica granatum L.) as a Tannin rich Fruit: a review. The 1st International and The 4th National Congress on Recycling of Organic Waste in Agriculture.

[15] Asmardi, Arifan, Rodesia Mustika Roza, Fitmawati. 2014. Aktivitas Antibakteri Ekstrak Daun Cyclea Barbata (I.) Miers. 
terhadap Bakteri Escherichia coli dan Salmonella typhi. JOM FMIPA. 1(2): 1-9.

[16] Azis, Tamzil, Sendry Febrizky, Aris D. Mario. 2014. Pengaruh Jenis Pelarut terhadap Persen Yieldalkaloid dari Daun Salam India (Murraya koenigii). Teknik Kimia. 2(20): 1-6.

[17] Faatih, M. 2005. Aktivitas Anti-Mikroba Kokon (Attacus atlas L.). J. Peneltian Sains \& Teknologi. 6 (1): 35-48.

[18] Putra, I. Amanda, Erly, dan Machdawaty Masri. 2015. Uji Efek Antibakteri Ekstrak Etanol Kulit Batang Salam \{Syzigium polyanthum (Wight) Walp\} terhadap Staphylococcus aureus dan Escherichia coli secara In vitro. Jurnal Kesehatan Andalas. 4 (2): 497-501.

[19] Tuntun, Maria. 2016. Uji Efektivitas Ekstrak Daun Pepaya (Carica papaya L.) terhadap Pertumbuhan Bakteri Escherichia coli dan Staphylococcus aureus. Jurnal Kesehatan. 7 (3): 497-502.

[20] Jannata, H. Jannata, Achmad Gunadi, dan Tantin Ermawati. Daya Antibakteri Ekstrak Kulit Apel Manalagi (Malus sylvestris Mill.) terhadap Pertumbuhan Streptococcus mutans. 2014. e-Jurnal Pustaka Kesehatan. 2 (1): 23-28.

[21] Putra, I Made Agus Sunadi. 2015. Uji Aktivitas Antibakteri Ekstrak Etanol Daun Sirsak (Annonae muricata L.) dengan Metode Difusi Agar Cakram Terhadap Escherichia coli. Medicamento. 1 (1): 1519.

[22] Hendra, R., Ahmad S., Sukari A., dan Shukor M. Y. 2011. Oskoueian E. Flavonoid Analyses and Antimicrobial
Activity of Various Parts of Phaleria Macrocarpa (Scheff.) Boerl Fruit. Int J Mol Sci. 12: 3422-3431.

[23] Cushnie, T.P. Tim., Andrew J. Lamb. 2005. Antimicrobial activity of flavonoids. International Journal of Antimicrobial Agents 26.

[24] Nuria, M.C., A. Faizatun., dan Sumantri. 2009. Uji Antibakteri Ekstrak Etanol Daun Jarak Pagar (Jatropha cuircas $L$ ) terhadap Bakteri Staphylococcus aureus ATCC 25923, Escherichia coli ATCC 25922, dan Salmonella typhi ATCC 1408. Jurnal IImu - ilmu Pertanian. 5: 26 - 37.

[25] Sari, F.P., dan S. M. Sari. 2011. Ekstraksi Zat Aktif Antimikroba dari Tanaman Yodium (Jatropha multifida Linn) sebgai Bahan Baku Alternatif Antibiotik Alami. Fakultas Teknik Universitas Diponegoro, Semarang.

[26] Karou, Savadogo, Canini, Yameogo, Montesano, Simpore, Colizzi, dan Traore. 2005. Antibacterial Activity of Alkaloids from Sida acuta. Afr. J. Biotechnol. 4 (12)

[27] Lenny, Sovia. 2006. Senyawa Flavonoida, Fenilpropanoida, dan Alkaloida. Tidak Diterbitkan. Karya IImiah. Departemen Kimia Fakultas MIPA Universitas Sumatra Utara. Medan: USU Repository

[28] Cowan, M. M. 1999. Plant product as Antimicrobial Agents. Clin. Microbiol. Rev. 12 (4). 